\title{
Distribution of mycosporine-like amino acids and photoprotective carotenoids among freshwater phytoplankton assemblages
}

\author{
Isabelle Laurion $^{1, *}$, Andrea Lami ${ }^{2}$, Ruben Sommaruga ${ }^{1, * *}$ \\ ${ }^{1}$ Institute of Zoology and Limnology, University of Innsbruck, Technikerstr. 25, 6020 Innsbruck, Austria \\ ${ }^{2}$ National Research Council, Institute of Hydrobiology, Verbania-Pallanza, Italy
}

\begin{abstract}
Phytoplankton have evolved different strategies to minimize the potential damage caused by solar ultraviolet radiation (UVR), including the synthesis of UV-absorbing compounds that act as sunscreens and carotenoids that provide protection against photooxidative stress. The concentration and qualitative composition of mycosporine-like amino acids (MAAs) and photoprotective carotenoids (PPCs) were investigated in natural phytoplankton assemblages of 26 lakes located below and above the treeline in the Alps and the Pyrenees. Among these lakes, exposure to UV varied because of differences in the incident spectral dose, water column transparency, stratification, and maximum depth. Seven MAAs were identified, but the most abundant were shinorine $\left(\lambda_{\max }=\right.$ $334 \mathrm{~nm}$ ) and palythine $\left(\lambda_{\max }=320 \mathrm{~nm}\right.$ ). The highest concentrations of MAAs (up to $9.6 \mu \mathrm{g}[\mu \mathrm{g} \mathrm{chl} \mathrm{a}]^{-1}$ ) and PPCs (up to $0.6 \mu \mathrm{g}[\mu \mathrm{g} \mathrm{chl} \mathrm{a}]^{-1}$ ) were found in the clearest and shallowest lakes, while phytoplankton from lakes with low UV transparency generally presented low values. However, phytoplankton of some clear lakes located at high altitude did not have high concentrations of these compounds. Consequently, underwater downwelling UVR, UV water transparency, or lake altitude explained only a low percentage $(<26 \%)$ of the variability among lakes in MAA and PPC concentration. Within the water column, the concentration of MAAs decreased in most cases with depth, suggesting their photoprotective role. Our results indicate that MAAs and PPCs are widespread among lake phytoplankton assemblages and suggest that other environmental factors besides UV exposure are important in regulating their synthesis.
\end{abstract}

KEY WORDS: MAA · Sunscreens $\cdot$ Ultraviolet radiation $\cdot$ UV $\cdot$ Solar radiation $\cdot$ Photooxidative stress · Alpine lakes

\section{INTRODUCTION}

Phytoplankton have a range of photoprotective mechanisms to minimize the potential damage caused by solar ultraviolet radiation (UVR; 290 to $400 \mathrm{~nm}$ ) that include, for example, the synthesis of UV-absorbing compounds and of carotenoids that act as direct sunscreens or against photooxidative stress, respectively (Roy 2000). Examples of UV-absorbing compounds are

*Present address: Institut des Sciences de la Mer, Université du Québec à Rimouski, 310 Allée des Ursulines, Rimouski, Québec G5L 3A1, Canada

${ }^{* *}$ Corresponding author. E-mail: ruben.sommaruga@uibk.ac.at scytonemin, an indol alkaloid with a maximum in vivo absorption at ca $370 \mathrm{~nm}$ found only in the sheath of mat-forming and epilithic cyanobacteria (GarciaPichel \& Castenholz 1991), and mycosporine-like amino acids (MAAs). MAAs are a family of watersoluble, low molecular weight compounds with high molar extinction coefficients ( $\varepsilon$ : 28100 to $50000 \mathrm{M}^{-1}$ $\mathrm{cm}^{-1}$ ) and absorption maxima between 309 and 360 $\mathrm{nm}$. MAAs have been found in phytoplankton cultures (Carreto et al. 1990, Marchant et al. 1991, Davidson et al. 1994, Helbling et al. 1996, Riegger \& Robinson 1997, Neale et al. 1998, Jeffrey et al. 1999, Xiong et al. 1999), natural marine phytoplankton assemblages (Karentz et al. 1991, Negri et al. 1992, Bidigare et al. 
1996, Bracher \& Wiencke 2000, Whitehead \& Vernet 2000), and zoozanthellae living in symbiosis with corals (Shick et al. 1999). Information on these compounds in natural freshwater phytoplankton and their photoprotective role is scarce. Sommaruga \& GarciaPichel (1999) measured the abundance and composition of MAAs in planktonic and benthic algal communities of a clear high mountain lake in the Central Alps. They found higher pigment-specific phytoplankton in vivo absorption (at $334 \mathrm{~nm}$ ) at the surface than in deeper layers in the water column. They also found high concentrations of MAAs in epilithic cyanobacteria. Benthic mat communities of a high altitude tropical lake also synthesized MAAs; however, phytoplankton did not appear to have such protection (Kinzie et al. 1998).

The frequently observed correlation between MAA concentration and solar exposure found in nature suggests that these compounds play an important role in UV protection. Moreover, experiments with the dinoflagellate Gymnodinium sanguineum have shown that MAAs indeed protect against inhibition of photosynthesis (Neale et al. 1998).

Besides the potential photodamage directly caused by UVR to cell targets, the interaction of this radiation with oxygen and various cell chromophores can result in the production of damaging reactive oxygen species. Algal cells, however, appear to have quenching mechanisms that allow them to detoxify these photochemical reaction products. Certain carotenoids have antioxidant activity while others participate in the xanthophyll cycle, which prevents photoinhibition by dissipating the excess light energy (see Roy 2000 and references therein). Accumulation of carotenoids specifically in response to UVR has been reported for cyanobacteria and chlorophytes (Buckley \& Houghton 1976, Bidigare et al. 1993, Goes et al. 1994), but there is little information about their distribution among natural freshwater phytoplankton assemblages.

In this study, our objectives were to assess (1) how widespread photoprotective compounds (MAAs and carotenoids) are among phytoplankton assemblages of lakes located across an altitude gradient and (2) the importance of UV exposure for the variability in the concentrations of these compounds. We addressed these objectives by means of profiles in a broad suite of lakes in several locations in Europe that revealed a large variability in MAA and carotenoid concentrations.

\section{MATERIALS AND METHODS}

Study sites. Twenty-six lakes in the Tyrolean Alps (Austria and Italy, $\mathrm{n}=19$ ) and in the Pyrenees (Spain, $\mathrm{n}=7$ ) were sampled in 1998 (see Laurion et al. 2000 for details). Four lakes (Mondsee [MON], Traunsee [TRA], Achensee [ACH], and Piburgersee [PIB]) are located in the pre-alpine region of the Alps at altitudes $<930 \mathrm{~m}$ above sea level (a.s.l.), while all others are situated above $1480 \mathrm{~m}$ a.s.l. Lake elevation ranges from 422 to $2799 \mathrm{~m}$ a.s.l. in the Alps and from 1900 to $2400 \mathrm{~m}$ a.s.l. in the Pyrenees (Table 1). The treeline is situated approximately at $2000 \mathrm{~m}$ in this region of the Alps and at $2200 \mathrm{~m}$ in the Pyrenees. Most lakes in the Alps were sampled in July and in October (MON and TRA sampled only in November), whereas lakes in the Pyrenees were sampled once in September. The ice-cover of some of the highest located lakes had recently melted when they were sampled in July, while in October, the ice-cover had started to build over Rotfelssee (ROT) and was already formed over Oberer Plenderlesee (OPL). Following Laurion et al. (2000), the lakes were separated into 3 categories according to the dominant catchment vegetation: lakes above the treeline with a poor soil cover or with less than $5 \%$ of sparse pine trees (hereafter 'exposed rock' category; $\mathrm{n}=11$ ), lakes at high altitudes but surrounded by alpine meadows (hereafter 'meadows'; $\mathrm{n}=5$ ), and lakes with forested catchments (hereafter 'trees'; $\mathrm{n}=10$ ).

Attenuation coefficient measurements. A PUV-500A radiometer (Biospherical Instruments Inc, San Diego, CA, USA) provided a measure of downwelling irradiance at $305,320,340$ and $380 \mathrm{~nm}$ (full bandwidth at half maximum is 8 to $10 \mathrm{~nm}$ ), and of downwelling photosynthetically available radiation (PAR; 400 to $700 \mathrm{~nm}$ ). The instrument also recorded depth, temperature, and upwelling radiance centered at $683 \mathrm{~nm}$ (naturally induced fluorescence). Details on the calculation of the diffuse attenuation coefficients of downwelling UVR $\left(K_{\mathrm{d}}\right)$ are given in Laurion et al. (2000). The fraction of the water column to which $1 \%$ of the surface UVR at $320 \mathrm{~nm}$ penetrated $\left(Z_{1 \%}: Z_{\max }\right)$ was calculated from $K_{\mathrm{d}}$ (at $320 \mathrm{~nm}$ ) and the maximum lake depth (Table 1).

Chlorophyll a (chl a), UV-absorbing compounds, and carotenoids. The lake water was sampled at 1 to 5 discrete depths with a modified 51 Schindler-Patalas sampler in the Alps or a Ruttner bottle in the Pyrenees and samples were kept in the dark (and cold when possible) until processed in the laboratory (within $\sim 6 \mathrm{~h}$ ). The selection of sampling depths was based on profiles of PAR and induced chl a fluorescence as measured with a Backscat I-Fluorometer (Haardt, Kleinbarkau, Germany, model 1101.1; excitation 380 to $540 \mathrm{~nm}$, emission $685 \mathrm{~nm}$ ). A sub-sample of lake water $(250 \mathrm{ml})$ was fixed with acidified Lugol's solution and maintained in the dark at $4^{\circ} \mathrm{C}$ for further qualitative microscopic analysis. Three separate filters were prepared for chl a, MAAs, and carotenoid analyses. The 


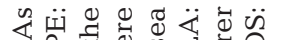

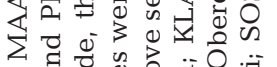

๘ व

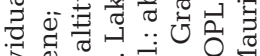

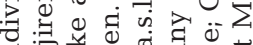

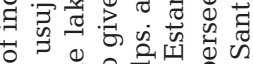

पू

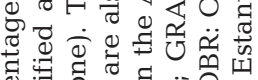

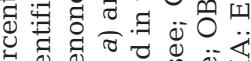

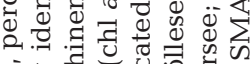

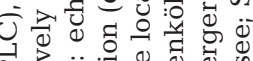

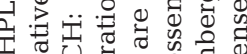

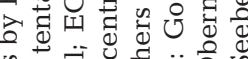

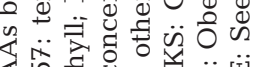

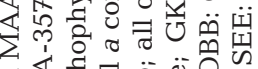

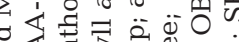

茫范范

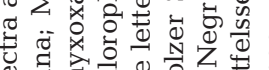

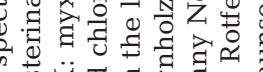

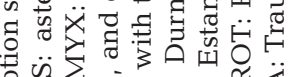

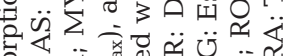

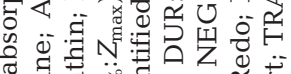

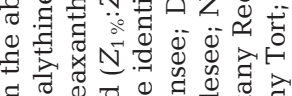

घี

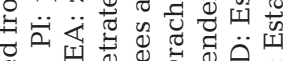

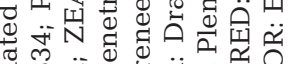

m.

ठ

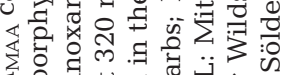

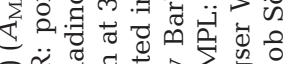

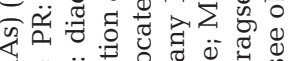

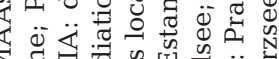

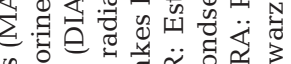

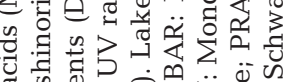

च

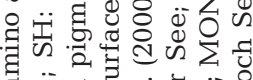

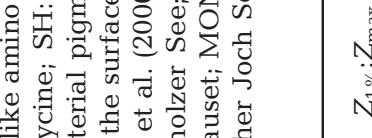

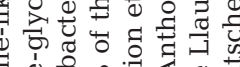

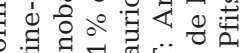

贾

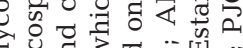

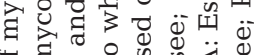

믄

荨

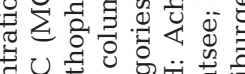

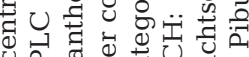

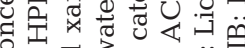

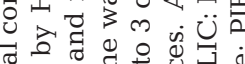

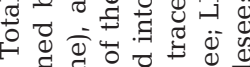

$-i$ 舟

$\circlearrowleft$ :

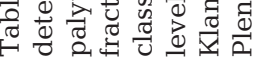

峁

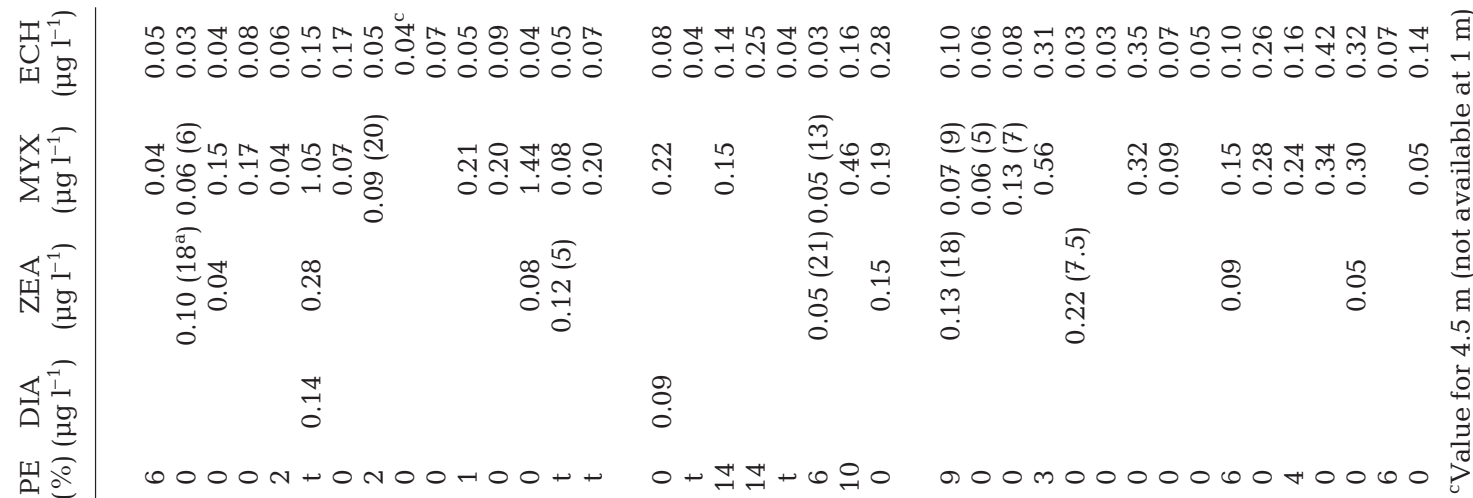

is

mOONM M

$0 \infty \vec{A}++0$ तु०

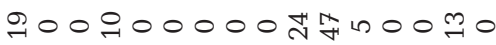

赵送

+n

$0++00 m++$

$000 m 00000+04+m 00$

$\overline{2} \overline{0}$

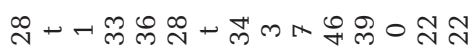

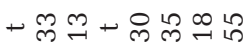

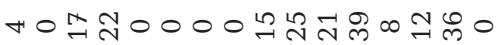

준

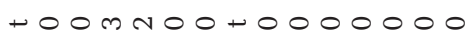

00000000

昰

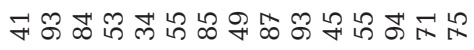

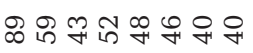

$000000000++00000$

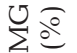

FOONMU MOO

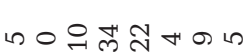

융요

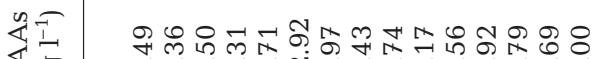

००

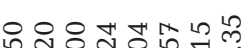

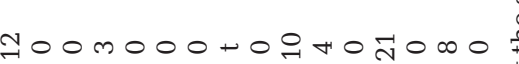

$\Sigma \equiv$

एक्ष

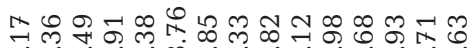

00 ino0ing

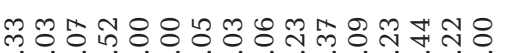
0000000004070000

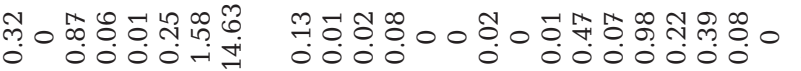

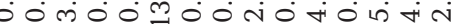

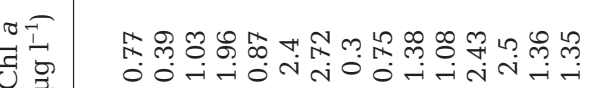

సี

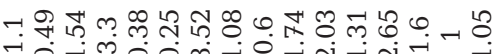

riongotin

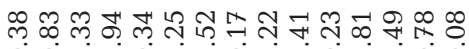

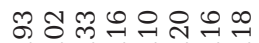

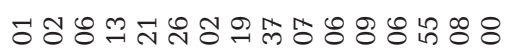

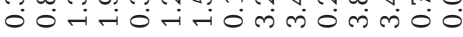
0 -io00000

0000000000000000

을

윰

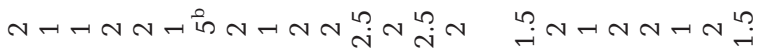

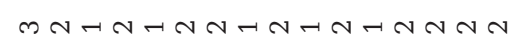

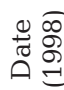

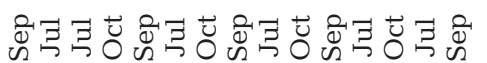

इ

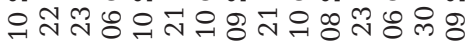

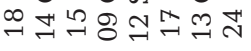

引

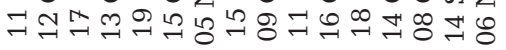

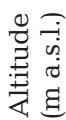

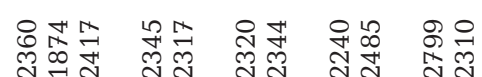

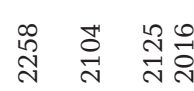

๙ิ 윰

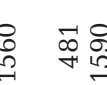

竔 눙

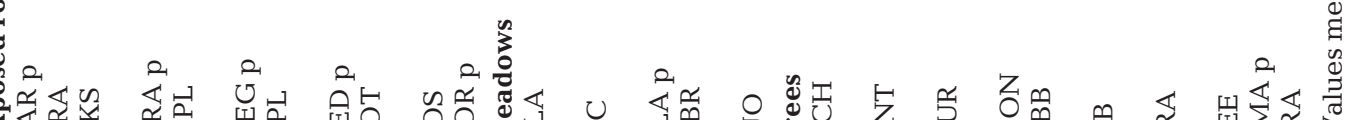

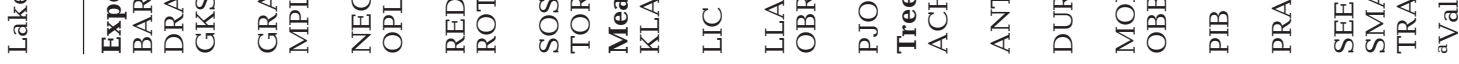


lake water was pre-screened by a $100 \mu \mathrm{m}$ mesh to remove large zooplankton that bioaccumulate carotenoids and MAAs in high concentrations (Sommaruga \& Garcia-Pichel 1999). However, a bias may have been introduced from MAAs present in small rotifers (Tartarotti et al. 2001) and other microzooplankton.

For chl a measurements, 0.6 to 3.51 of lake water was filtered onto glass fiber filters (Whatman GF/F) and frozen at $-20^{\circ} \mathrm{C}$ until subsequent extraction (within $3 \mathrm{wk}$ ). Pigments were extracted in $12.5 \mathrm{ml}$ of $90 \%$ alkaline acetone (v:v) for $24 \mathrm{~h}$ in the dark at $4^{\circ} \mathrm{C}$. Filters were briefly sonicated with a tip sonicator (1 $\mathrm{min})$ on an ice bath and the extracts cleared using a $0.1 \mu \mathrm{m}$ pore size Anodisc filter (Whatman). The extracts were scanned in a spectrophotometer (double beam Hitachi U-2000; scans between 400 and $750 \mathrm{~nm}$ ) against an acetone reference and using $5 \mathrm{~cm}$ glass cuvettes. The optical density measured at $664 \mathrm{~nm}$ always remained above 0.03 and in most cases was more than 1 order of magnitude higher than the optical density at $750 \mathrm{~nm}$. The equations of Jeffrey \& Humphrey (1975) were used to calculate the concentration of pigments.

For MAA measurements, 0.8 to 4.851 of lake water was filtered onto glass fiber filters (Whatman GF/F) and frozen at $-80^{\circ} \mathrm{C}$ until subsequent extraction (within 4 mo). MAAs were extracted in 12.5 or $15 \mathrm{ml}$ of $20 \%$ aqueous methanol (v:v) in the dark for $24 \mathrm{~h}$ at $4^{\circ} \mathrm{C}$, followed by a $2 \mathrm{~h}$ extraction in a water bath at $45^{\circ} \mathrm{C}$ (Sommaruga \& Garcia-Pichel 1999). Filters were sonicated, and the extracts were clarified and scanned as above (scans between 250 and $750 \mathrm{~nm} ; 5 \mathrm{~cm}$ SUPRASIL I quartz cuvette), to obtain a general view on the combined UV-absorbing compounds. The extracts were subsequently dried under vacuum in $2 \mathrm{ml}$ cryovials, using a SpeedVac concentrator (Savant) at $45^{\circ} \mathrm{C}$. The air in the cryovials was replaced with argon, and the samples were stored at $-80^{\circ} \mathrm{C}$ for further characterization using high performance liquid chromatography (HPLC). The concentrated extracts were resuspended in 0.5 to $2 \mathrm{ml}$ of $55 \%$ aqueous methanol (v:v). When the concentration in this solution was too high, a small portion was subsampled for further dilution. MAAs were separated by reverse-phase isocratic HPLC, injecting $10 \mu \mathrm{l}$ aliquots in a Brownlee (Perkin Elmer Corp., Shelton, CT, USA) RP-8 column (Spheri-5; $4.6 \mathrm{~mm}$ inner diameter [i.d.] $\times$ $250 \mathrm{~mm}$ ) protected by an RP-8 guard (4.6 mm i.d. $\times$ $30 \mathrm{~mm}$ ), in a mobile phase of $0.1 \%$ acetic acid in $55 \%$ aqueous methanol (Carefoot et al. 1998). The MAAs in the eluate were detected by online UV spectroscopy. Peaks were measured at 313 and 340 nm (Karentz et al. 1991). The MAAs were identified by comparison with retention times (order of appearance; see Fig. 6A), by the ratio of peak areas determined at 313 and $340 \mathrm{~nm}$ and by co-chromatography with purified standards (obtained from Dr F. GarciaPichel) or with secondary standards prepared from invertebrate extracts (Aplysia dactylomela eggs obtained from Dr D. Karentz, and Anthopleura sp. and Palythoa sp. obtained from Dr M. Shick). Additionally, several samples were cross-checked with another HPLC system equipped with a diode array detector (Dionex Corp., Sunnyvale, CA, USA) to confirm the identity of the different MAAs. The total content of specific MAAs in each sample was calculated from HPLC peak areas, using published extinction coefficients (see Tartarotti et al. 2001). The extinction coefficient for asterina-330 (AS) has not been reported in the literature but that of palythinol, a nearly identical chromophore, was consequently adopted (Dunlap et al. 1989).

For carotenoid measurements, 0.6 to $3.4 \mathrm{l}$ of lake water was filtered onto glass fiber filters (Whatman $\mathrm{GF} / \mathrm{F}$ ) and frozen at $-20^{\circ} \mathrm{C}$ until subsequent extraction (within $8 \mathrm{mo}$ ). The carotenoids were extracted for ca $10 \mathrm{~h}$ with 2 to $6 \mathrm{ml}$ of $90 \%$ aqueous acetone $(\mathrm{v}: \mathrm{v})$, and the extracts were cleared by centrifugation. The HPLC (System Gold Beckman) comprised a double pump module for gradient elution, a visible UV (UV/VIS) detector, and a diode array detector. The acetone extract was first read in the UV/VIS spectrophotometer, with absorbance spectra recorded between 350 and $800 \mathrm{~nm}$. Pigments were then separated by reverse-phase HPLC, injecting $300 \mu \mathrm{l}$ aliquots in a Beckman Hypersil ODS C-18 column ( $5 \mu \mathrm{m} ; 4.6 \mathrm{~mm}$ i.d. $\times 250 \mathrm{~mm}$ ) protected by a Hypersil guard column (4.6 mm i.d. $\times 45 \mathrm{~mm}$ ). The elution mixture was based on Mantoura \& Llewellyn (1983) with some modifications. Solvent mixtures that gave the best separation were as follows: solvent A, 80:20 methanol:water (propionic acid and butyl-ammonium phosphate buffer were added to the water as ion pairing agents with a final concentration of $1 \mathrm{mM}$ of each); and solvent $B, 60: 40$ acetone:methanol. The initial condition was a flow rate of $1 \mathrm{ml} \mathrm{min}^{-1}$ and $15 \%$ solvent B followed by a linear gradient to $95 \%$ B over 45 min with a parallel flow rate gradient from 1 to $2 \mathrm{ml} \mathrm{min} \mathrm{mi}^{-1}$ and subsequent isocratic elution to 55 min. Pigments were identified by co-chromatography with commercially available primary standards (Water Quality Institute, VKI, Hørsholm, Denmark) or with culture material purified by thin-layer chromatography (donated by Hoffman La Roche, Vitamin Research and Technical Development Laboratory, Basel, Switzerland).

Data analysis. All statistical analyses were performed with the Sigma-Stat 2.03 software package (SPSS Inc., Chicago, IL, USA). The Shannon-Wiener diversity index (Zar 1999) was used to calculate the diversity of MAAs. 

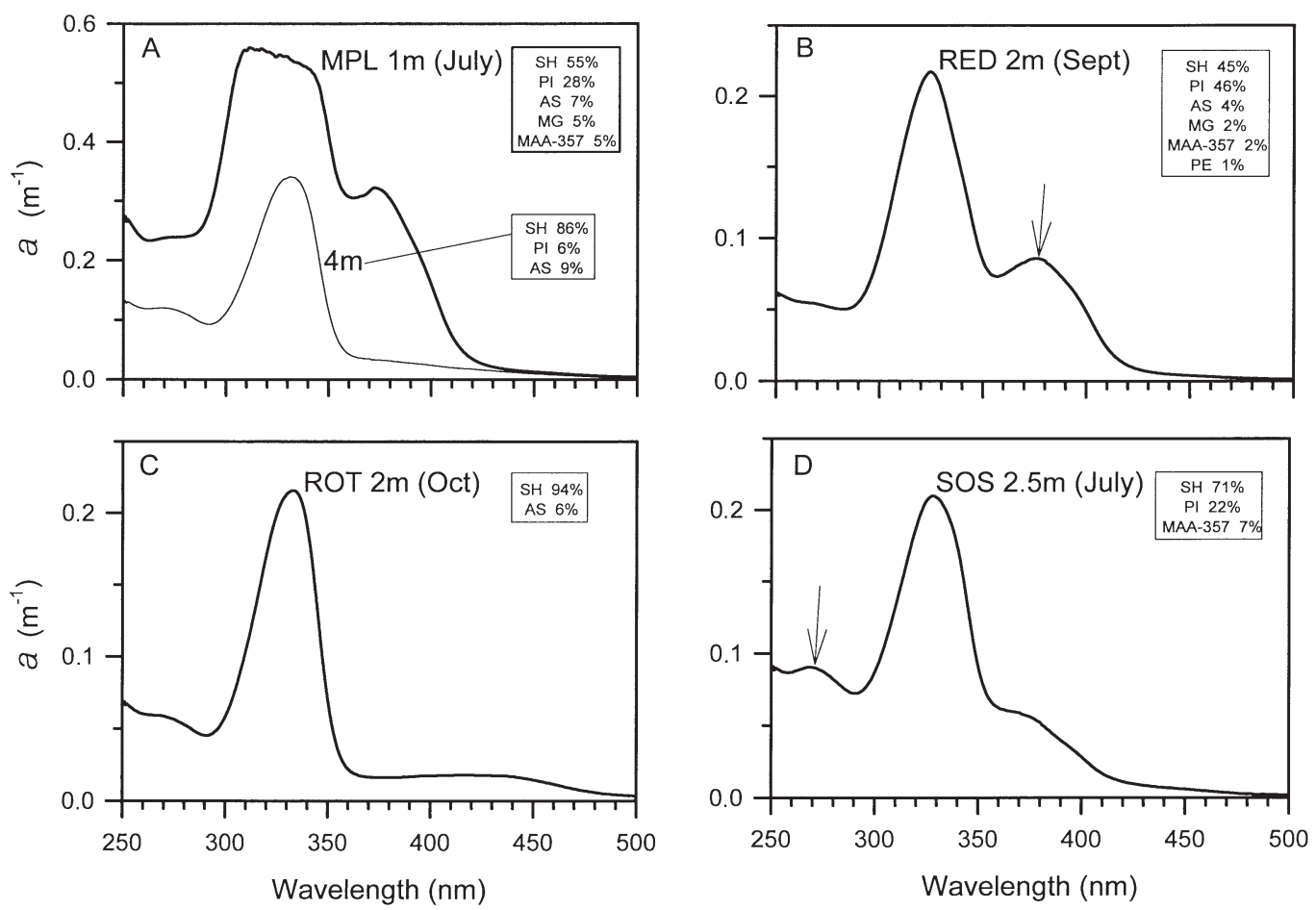

Fig. 1. Absorption (a) spectra of aqueous methanol extracts (20\%) for (A) Mittlere Plenderlesee (MPL) in July at 1 and $4 \mathrm{~m}$ (thin line), (B) Estany Redo (RED) at 2 m, (C) Rotfelssee (ROT) in October at $2 \mathrm{~m}$, and (D) Schwarzsee ob Sölden (SOS) at $2.5 \mathrm{~m}$. The mycosporine-like amino acids (MAAs) identified by HPLC are indicated as a percentage of the total MAA concentration (SH: shinorine; PI: palythine; AS: asterina; MG: mycosporine-glycine; MAA-357: tentatively identified as usujirene; PE: palythene). Arrows indicate the absorption peaks at 270 and $375 \mathrm{~nm}$

\section{RESULTS}

\section{Total concentration of UV-absorbing compounds}

The phytoplankton assemblages in this lake series showed diverse combinations of UV-absorbing compounds (Fig. 1). The spectral shapes shown in Fig. 1 result from the varying composition of MAAs and other compounds absorbing from ca $285 \mathrm{~nm}$ to $>400 \mathrm{~nm}$. In several cases, peaks around $270 \mathrm{~nm}$ (e.g., Fig. 1D), and 375 to $380 \mathrm{~nm}$ (e.g., Figs 1B \& 2) were apparent. The latter peak likely corresponds to scytonemin, but as it was not eluted on the chromatograms and no standard was available, it will be referred as to $\mathrm{UAC}_{375}$ hereafter.

An indirect estimation of total concentration of MAAs ( $A_{\text {MAA }}$ in $\mathrm{nm} \mathrm{m}^{-1}$; Table 1 ) was first obtained by integrating the area under the absorption maximum centered around $330 \mathrm{~nm}$ on the methanol extracts (the integration from ca 285 to $360 \mathrm{~nm}$ ranged from 0 to $18.8 \mathrm{~nm} \mathrm{~m}^{-1}$ ). This estimation compared well to the total concentration of MAAs obtained by HPLC (MAAs $\left.=0.995 A_{\mathrm{MAA}}+0.1742, \mathrm{r}^{2}=0.90, \mathrm{p}<0.001, \mathrm{n}=83\right)$. Moreover, the wavelength at peak maximum was coin- cident with the absorption maximum of the most abundant MAA.

Total MAA concentration for surface values ranged from undetectable to $22.9 \mathrm{\mu g} \mathrm{l}^{-1}$ (average of $1.96 \mu \mathrm{g}$ $\mathrm{l}^{-1}, \mathrm{n}=39$ ) or when normalized to the chl a content (hereafter chl $a$-specific concentration), from undetectable to $9.6 \mu \mathrm{g}[\mu \mathrm{g} \mathrm{chl} \mathrm{a}]^{-1}$ (average of $1.13 \mu \mathrm{g}[\mu \mathrm{g}$ $\operatorname{chl} a]^{-1}, \mathrm{n}=39$ ). One of the highest MAA concentration was found in Pfitscher Joch See (PJO) with $17.9 \mathrm{\mu g} \mathrm{l}^{-1}$ at the surface; however, the chl a-specific concentration remained only slightly above the average $\left(2.3 \mu \mathrm{g}[\mu \mathrm{g} \mathrm{chl} \mathrm{a}]^{-1}\right)$. The highest MAA concentration (absolute and chl a-specific) was found in Mittlere Plenderlesee (MPL). Estany Redo (RED) also presented one of the highest chl a-specific concentrations of MAAs in the epilimnion. The highest chl aspecific concentration of $\mathrm{UAC}_{375}$ was also found in MPL and RED (data not shown). In general, the MAA concentration among the lakes appeared to be higher in July than in October (averages for July and October are 1.18 and $0.44 \mu \mathrm{g}[\mu \mathrm{g} \mathrm{chl} \mathrm{a}]^{-1}$, respectively), but the difference for the whole data set was not significant (Wilcoxon Signed rank test, $\mathrm{p}=0.3529$, $\mathrm{n}=18)$. 

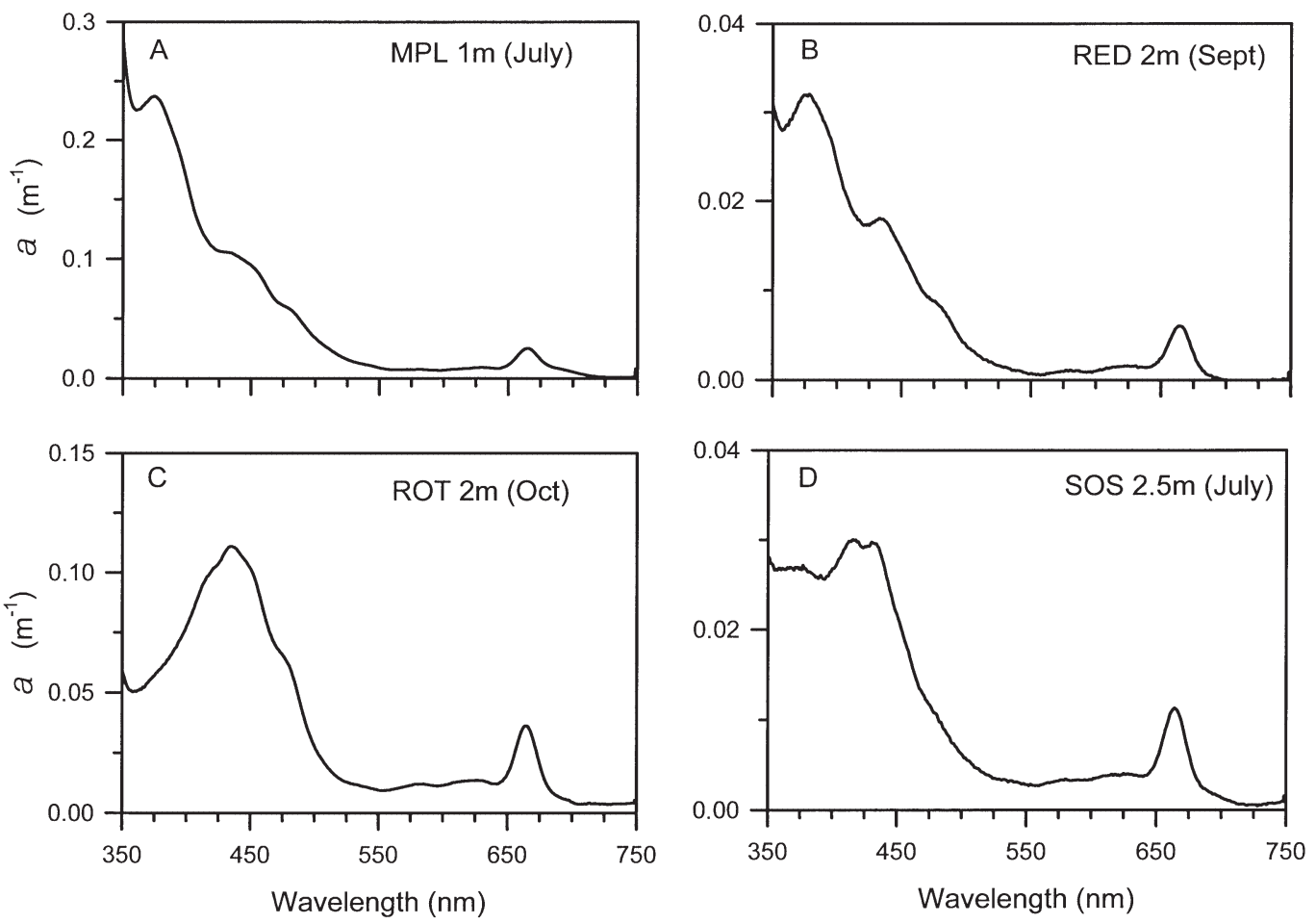

Fig. 2. Absorption (a) spectra of acetone extracts for (A) MPL in July at $1 \mathrm{~m}$, (B) RED at $2 \mathrm{~m}$, (C) ROT in October at $2 \mathrm{~m}$, and (D) $\mathrm{SOS}$ at $2.5 \mathrm{~m}$

\section{MAA composition}

The most abundant MAAs found in the lake series were shinorine $(\mathrm{SH})$ and palythine $(\mathrm{PI})$, representing on average 61 and $22 \%$ of the total MAAs, respectively (Table 1). Mycosporine-glycine (MG), porphyra-334 (PR), AS, palythene (PE), and 1 unknown UV-absorbing compound with a maximum absorption at $357 \mathrm{~nm}$, tentatively identified as usujirene (Tsujino et al. 1979) and referred as to MAA-357 hereafter, were present from trace levels up to $47 \%$ of the total identified MAA pool. In the transparent Gossenköllesee (GKS), for example, $\mathrm{SH}$ was the most abundant MAA (water column average of $82 \%$ ), followed by AS (14\%) and PI (5\%). Lichtsee (LIC) in July, Obersee (OBR) in October, and PIB in July contained the highest diversity of MAAs (Shannon-Wiener diversity index $=0.63$; average for surface waters of all lakes $=0.36$ ). The phytoplankton of several lakes presented a low diversity of MAAs, with more than $93 \%$ of the total identified MAAs composed of SH (Drachensee [DRA], OPL in October, ROT in October, $\mathrm{ACH}$ in October, MON, and Obernbergersee [OBB]). The contribution of PR was always low $(<3 \%)$. Lake LIC had especially high concentrations of MG and PE (34 and $14 \%$, respectively, in October), 2 MAAs that were normally found in lower proportions (on average 5 and $2 \%$, respectively).

\section{Depth distribution of MAAs}

In most lakes, the chl a-specific concentration of MAAs was highest at the surface and decreased with depth (Fig. 3A), with surface values significantly higher than values at the bottom (or at the deepest sampled point; Wilcoxon signed rank test, $\mathrm{p}<0.001, \mathrm{n}=26$ ). However, in some cases (e.g., in DRA, GKS, and Schwarzsee ob Sölden [SOS]) a sub-surface maximum was present (Fig. 3B). Only in OBB (July) and PIB (October) did the chl a-specific MAA concentration increase with depth (16.5 and 1.4 times more concentrated at 6 and $11 \mathrm{~m}$ than at the surface, respectively). The composition was generally similar throughout the water column, with the exception of MPL, where the proportion of SH increased with depth while PI and other MAAs decreased (see Fig. 1A), OBR, where the proportion of MG, MAA-357, and $\mathrm{PE}$ increased with depth (only significant for MAA357; $\mathrm{r}^{2}=0.90, \mathrm{p}=0.0477$ ), and $\mathrm{ACH}$, where the MAA composition in October completely differed between 2 and $5 \mathrm{~m}$ depth (SH and MG + PI, respectively).

\section{Carotenoids}

The analysis of the acetone extracts revealed the presence of pigments characteristic of major algal 


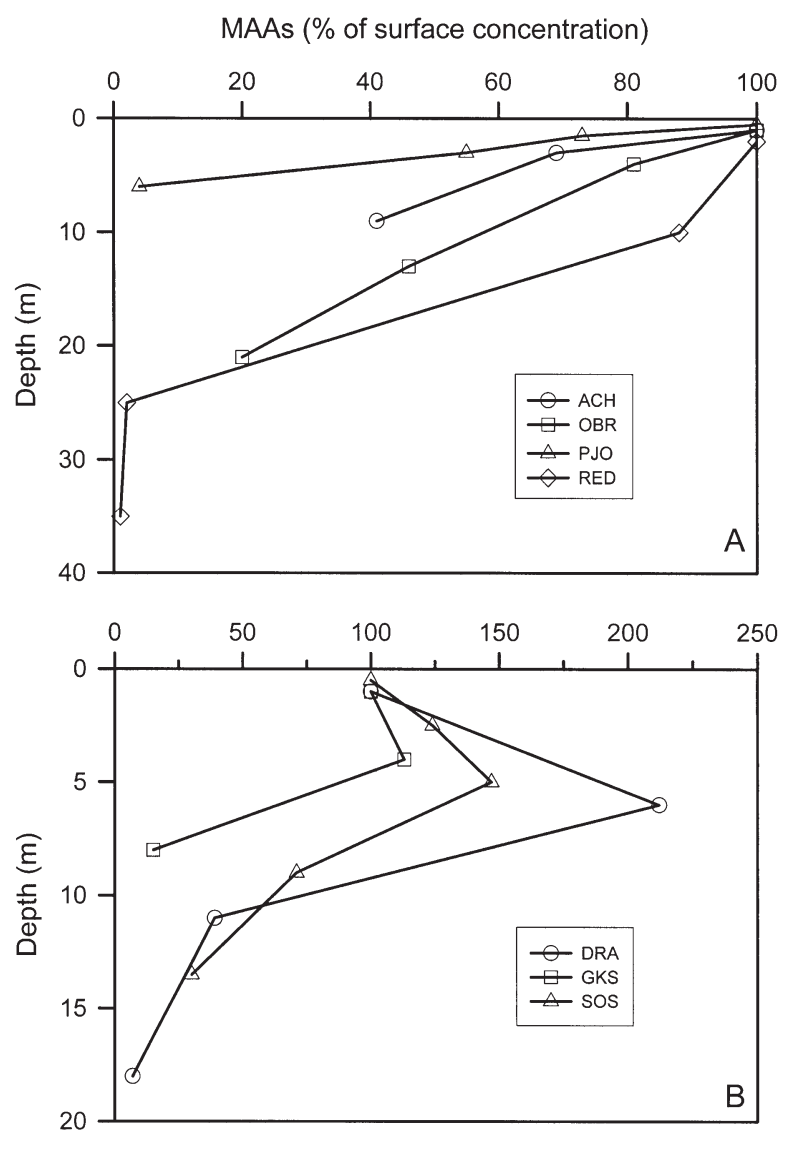

Fig. 3. Depth distribution of chl a-specific MAA concentrations expressed as a percentage of surface value in (A) Achensee $(\mathrm{ACH})$, Obersee (OBR), Pfitscher Joch See (PJO), and RED and (B) Drachensee (DRA), Gossenköllesee (GKS) and SOS during July (except for RED in September). Other lake abbreviations as in previous figures

groups such as dinoflagellates, chrysophytes, chlorophytes, and cyanobacteria. For example, the presence of peridinin (in deeper waters of Antholzer See [ANT] and ROT), alloxanthin (in deeper waters of GKS and in ROT in October), and lutein (in MPL) indicated the presence of dinoflagellates, cryptophytes, and chlorophytes, respectively. Three photoprotective carotenoids (PPCs) were identified in the chromatograms: diadinoxanthin (DIA), zeaxanthin (ZEA), and myxoxanthophyll (MYX). DIA was only detected in MPL and Klammsee (KLA), while varying concentrations of ZEA and MYX (generally associated with cyanobacteria) were found in several lakes (Table 1). The secondary carotenoid, echinenone $(\mathrm{ECH})$, was detected in all lakes (range 0.03 to $0.82 \mu \mathrm{g} \mathrm{l}^{-1}$ ), indicating the importance of cyanobacteria in mountain lakes. Concentrations of this pigment normalized to the chl a content were not significantly different between surface and deep layers (paired $t$-test, $\mathrm{p}=$ $0.1559, \mathrm{n}=26$ ).
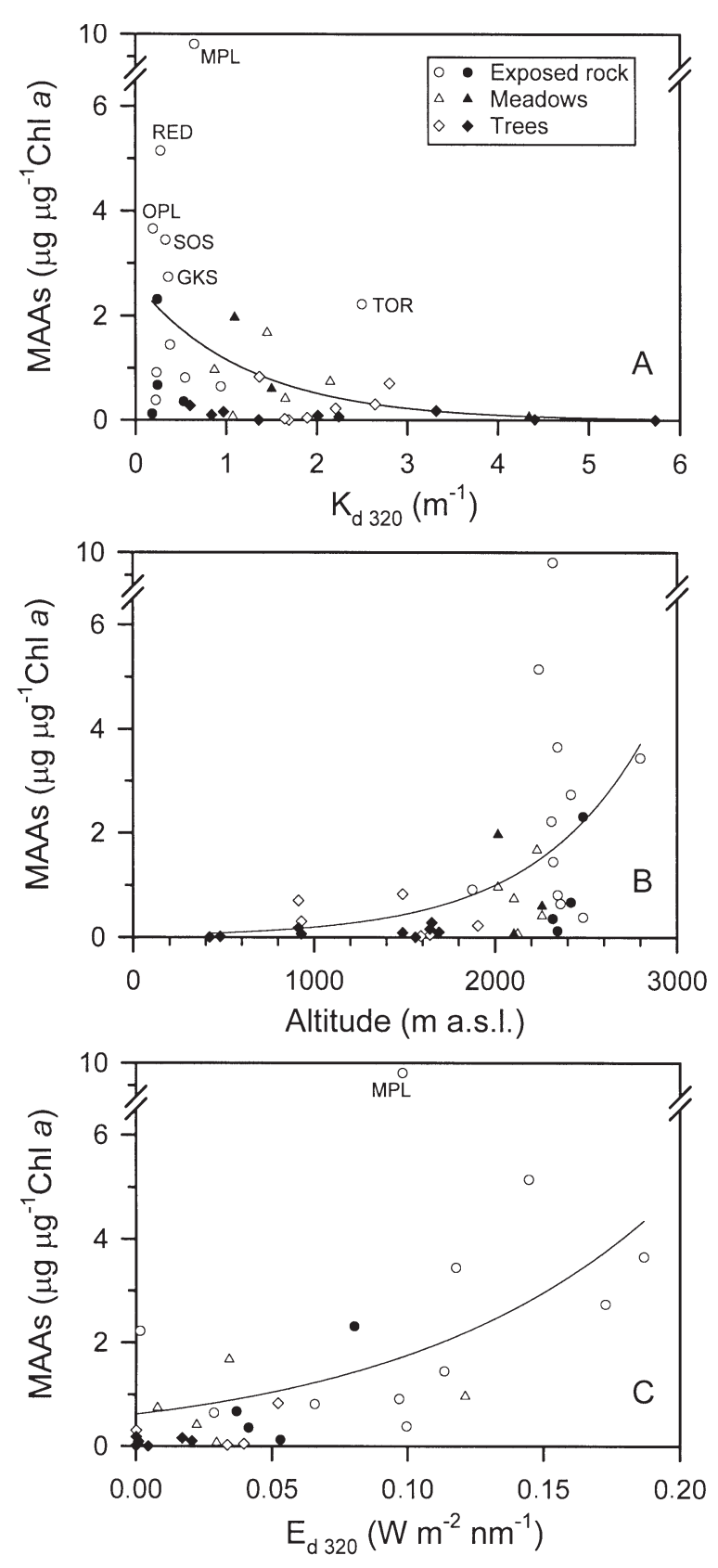

Fig. 4. Relationships between the chl a-specific concentration of MAAs and $(\mathrm{A})$ the attenuation coefficient $\left(K_{\mathrm{d}}\right)$ at $320 \mathrm{~nm}$, (B) the lake altitude, and (C) the underwater downwelling irradiance at sampling depth $\left(E_{\mathrm{d}}\right)$ at $320 \mathrm{~nm}$ (only data at the lake surface were used). Open symbols are for July or September sampling; filled symbols, for October or November. a.s.l.: above sea level; OPL: Oberer Plenderlesee; TOR: Estany Tort. Other lake abbreviations as in previous figures

\section{Variability among lakes}

A negative exponential relationship was found between surface values of chl a-specific MAA concentrations and the $K_{\mathrm{d}}$ at $320 \mathrm{~nm}\left(\mathrm{r}^{2}=0.15, \mathrm{p}=0.0156, \mathrm{n}=\right.$ 39, Fig. 4A). Generally, the highest MAA concentra- 


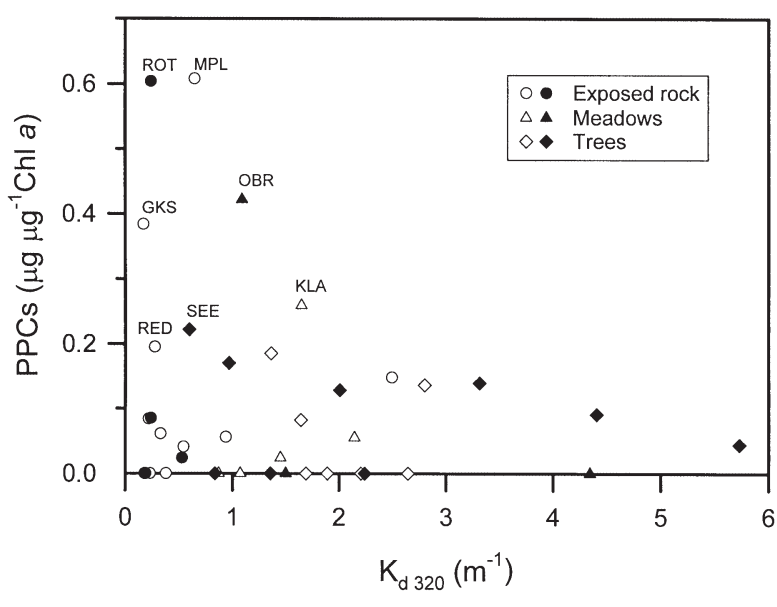

Fig. 5. Relationship between the chl a-specific concentration of photoprotective carotenoids (PPCs; diadinoxanthin, zeaxanthin, and myxoxanthophyll) and $K_{\mathrm{d}}$ from $320 \mathrm{~nm}$ (only data at the lake surface were used). Open symbols are for July or September sampling; filled symbols, for October or November. KLA: Klammsee; SEE: Seebensee. Other lake abbreviations as in previous figures

tions were found in the clearest lakes (MPL, RED, OPL, SOS, and GKS), but there were some exceptions; for example, ROT in July, and GKS and OPL in October. On the other hand, lakes with low UV transparency generally presented low MAA concentrations (e.g., $\mathrm{ACH}, \mathrm{LIC}, \mathrm{MON}, \mathrm{PIB}$, Pragser Wildsee [PRA], and TRA), especially when sampled in October. Thus, lakes PIB and PRA had relatively high MAA concentrations in July, but only in surface waters (more than an order of magnitude higher at the surface than at depth). The high-altitude Estany Tort (TOR) (2310 m a.s.l.) presented particularly high concentrations of MAAs despite its low transparency to UV $\left(K_{\mathrm{d}}\right.$ at $320=$ $2.50 \mathrm{~m}^{-1}$ compared to an average of $0.53 \mathrm{~m}^{-1}$ for the exposed rock lake category), but only in surface waters $\left(2.21\right.$ and $0.19 \mu \mathrm{g}$ MAAs $[\mu \mathrm{g} \mathrm{chl} \mathrm{a}]^{-1}$ at 2 and $8 \mathrm{~m}$, respectively). An exponential relationship was also obtained for chl a-specific MAA concentrations versus lake altitude $\left(\mathrm{r}^{2}=0.21, \mathrm{p}=0.0147, \mathrm{n}=39\right.$; Fig. 4B) or against the absolute downwelling UV irradiance at sampling depth $\left(E_{\mathrm{d}}\right.$ at $320 \mathrm{~nm}, \mathrm{r}^{2}=0.26, \mathrm{p}=$ $0.0027, \mathrm{n}=32$; Fig. 4C). Only measurements of downwelling irradiance under a sunny sky or scattered clouds were used in this regression.

Total chl $a$-specific carotenoid concentration showed no clear relationship with UV transparency, but when PPCs were plotted against $K_{\mathrm{d}}($ at $320 \mathrm{~nm}$ ), the relationship, although not significant, resembled the one found for MAAs ( $p>0.05$; Fig. 5). However, several compounds detected by HPLC (see Fig. 6B) displaying typical carotenoid absorption spectra could not be identified. Some of these compounds could have been photoprotective, yet there were no noticeable altitudeor depth-related changes in the major unidentified carotenoids.

\section{DISCUSSION}

\section{Concentration of MAAs and comparison with other studies}

The MAA concentration in this series of lakes was generally comparable to or exceeded the chl a concentration (average of $1.13 \mu \mathrm{g}$ MAA $[\mu \mathrm{g} \mathrm{chl} \mathrm{a}]^{-1}$ ) and reached up to $9.5 \mu \mathrm{g}$ MAA $[\mu \mathrm{g} \mathrm{chl} \mathrm{a}]^{-1}$ in MPL. The MAA concentrations were comparable to those reported in other studies with cultured phytoplankton species as well as with natural marine and freshwater phytoplankton assemblages (Table 2). However, the comparison must be done with caution because, as suggested by Sommaruga \& Garcia-Pichel (1999), different extraction protocols may give contrasting results. For example, chl a-specific MAA concentrations measured in GKS during summer 1996 (Sommaruga \& Garcia-Pichel 1999) were within the same range as values measured in 1998 (this study), but only for the extractions made with $20 \% \mathrm{MeOH}$.
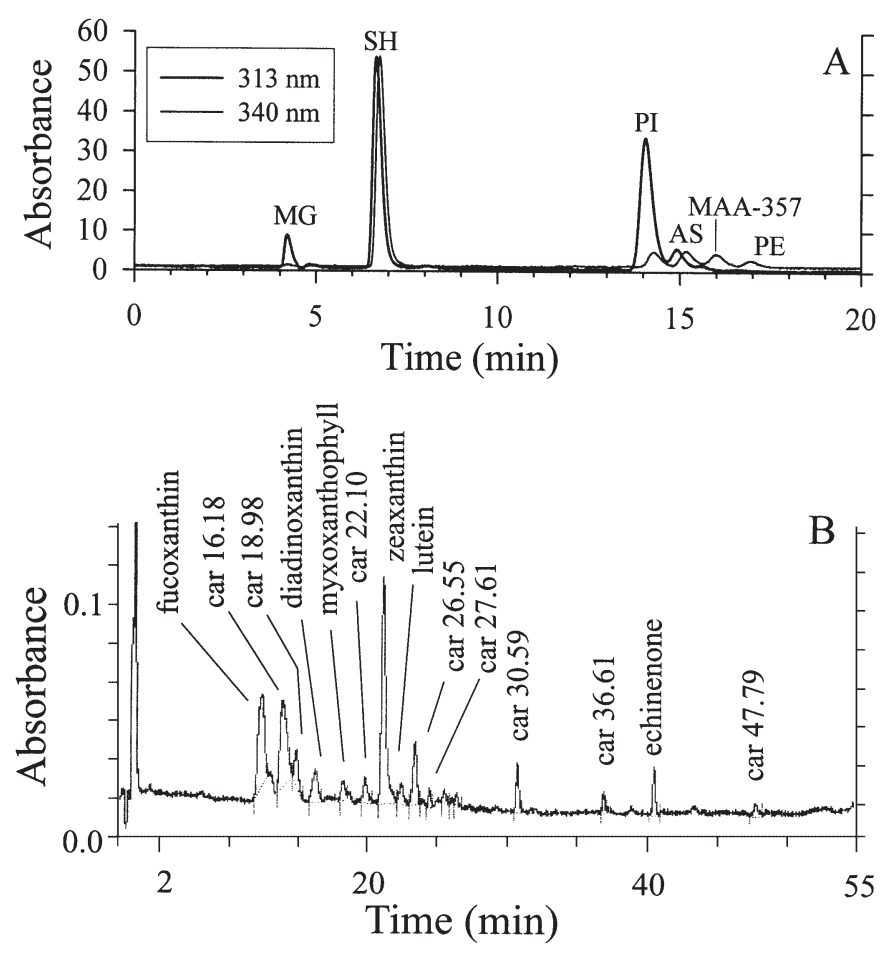

Fig. 6. Chromatograms for MPL in July at $1 \mathrm{~m}$ for (A) MAAs (see Table 1 for abbreviations) and (B) carotenoids (detection wavelength: $460 \mathrm{~nm}$ ). car: unidentified carotenoid followed by its retention time 
Table 2. Comparison of MAA concentrations in different marine and freshwater phytoplankton assemblages. MW: molecular weight

\begin{tabular}{|c|c|c|c|c|}
\hline Material studied & $\begin{array}{l}\text { MAA conc. } \\
\mu \mathrm{g}[\mu \mathrm{g} \mathrm{chl} a]^{-1}\end{array}$ & $\begin{array}{l}\text { Original data (when different) } \\
\text { and comments }\end{array}$ & Extraction method & Source \\
\hline \multicolumn{5}{|l|}{ Natural lake phytoplankton } \\
\hline GKS only & 0.3 to 2.7 & & \multirow{2}{*}{\multicolumn{2}{|c|}{$\begin{array}{c}20 \% \mathrm{MeOH} \\
24 \text { h at } 4^{\circ} \mathrm{C}+2 \mathrm{~h} \text { at } 45^{\circ} \mathrm{C}\end{array}$}} \\
\hline All 26 lakes & 0 to 9.5 & & & \\
\hline $\begin{array}{l}\text { Natural lake phytoplankton } \\
\text { (GKS) }\end{array}$ & 0.3 to 0.7 & $\begin{array}{l}\quad 0.015 \text { to } 0.053 \mu \mathrm{g}[\mu \mathrm{g} \mathrm{chl} \mathrm{a}]^{-1} \\
\text { when extracted in } 90 \% \mathrm{MeOH} \text { at } 4^{\circ} \mathrm{C}\end{array}$ & $\begin{array}{c}20 \% \mathrm{MeOH} \\
2 \mathrm{~h} \text { at } 45^{\circ} \mathrm{C}\end{array}$ & $\begin{array}{c}\text { Sommaruga \& } \\
\text { Garcia-Pichel (1999) }\end{array}$ \\
\hline $\begin{array}{l}\text { Natural marine } \\
\text { phytoplankton }\end{array}$ & Up to $\sim 1.3$ & $\begin{array}{c}\text { Up to } \sim 1 \mu \mathrm{gl}^{-1} \\
\text { Chl a range given: } 0.8 \text { to } 2.43 \mu \mathrm{g} \mathrm{l} \mathrm{l}^{-1}\end{array}$ & $\begin{array}{c}25 \% \mathrm{MeOH} \\
4 \mathrm{~h} \text { at } 45^{\circ} \mathrm{C}\end{array}$ & $\begin{array}{l}\text { Bracher \& Wiencke } \\
\qquad(2000)\end{array}$ \\
\hline $\begin{array}{l}\text { Marine dinoflagellate } \\
\text { cultures }\end{array}$ & 0.7 and 14 & $\begin{array}{l}\text { Algae grown under } \\
15 \text { and } 76 \mathrm{~W} \mathrm{~m}^{-2}\end{array}$ & $\begin{array}{c}100 \% \mathrm{MeOH} \\
\text { overnight at } 4^{\circ} \mathrm{C}\end{array}$ & Neale et al. (1998) \\
\hline $\begin{array}{l}\text { Natural marine } \\
\text { phytoplankton }\end{array}$ & $\sim 0.4$ to 2 & & $\begin{array}{c}100 \% \mathrm{MeOH} \\
6 \mathrm{~h} \text { at } 4^{\circ} \mathrm{C}\end{array}$ & Villafañe et al. (1995) \\
\hline $\begin{array}{l}\text { Marine dinoflagellate cultures } \\
\text { and natural communities }\end{array}$ & Up to $\sim 21$ & $\begin{array}{l}\text { Up to } 69.6 \mathrm{nmol} \text { MAAs }\left[\mu \mathrm{g} \mathrm{chl} \mathrm{a}^{-1}\right. \\
\text { generic MAA MW }=300 \mathrm{~g} \mathrm{~mol}^{-1}\end{array}$ & $\begin{array}{c}100 \% \mathrm{MeOH} \\
\text { overnight at } 4^{\circ} \mathrm{C}\end{array}$ & $\begin{array}{l}\text { Whitehead \& Vernet } \\
\qquad(2000)^{\mathrm{a}}\end{array}$ \\
\hline
\end{tabular}

The close fit between MAA concentrations determined from the integration of the absorption peak in the UV band ( $\left.A_{\mathrm{MAA}}\right)$ and those obtained from HPLC may be of interest for studies that were solely based on absorption measurements. However, self-absorption by very high MAA concentrations or interference by other UV-absorbing material should be considered and explicitly checked by HPLC before this empirical relationship can be used.

\section{Depth distribution of MAAs}

The chl a-specific concentration of MAAs decreased with depth in most lakes (Fig. 3), even in cases where the water column was well mixed (such as in Estany Barbs [BAR], MPL, OBR in October, and in the epilimnion of PJO and RED), supporting the idea that MAAs were synthesized in response to UV exposure. In $\mathrm{ACH}, \mathrm{MPL}$ (see Fig. 1A), and OBR, the MAA composition notably changed with depth, probably reflecting differences in community composition. In GKS, Sommaruga \& Garcia-Pichel (1999) found a decrease in MAA concentrations from the surface to $3 \mathrm{~m}$, followed by an increase to maximum values at the lake bottom. The proportion of $\mathrm{SH}$ and AS also changed with depth, SH being most abundant at the bottom. The increase in total MAAs and $\mathrm{SH}$ concentrations at depth, however, was caused by the presence of cyclopoid copepods that bioaccumulate high MAA concentrations, particularly of $\mathrm{SH}$ (Sommaruga \& Garcia-Pichel 1999). When measuring the pigmentspecific in vivo absorption of phytoplankton $(334 \mathrm{~nm})$, these authors found the highest values at the surface and a decrease with depth. Daily migration of phytoplankton most likely has a great impact on what is found in the water at the time of sampling. In the present study, we did not detect significant vertical differences in the composition of MAAs in GKS, suggesting that bias due to other members of the plankton, like small rotifers and ciliates that may have passed through the $100 \mu \mathrm{m}$ mesh net, was not significant. Moreover, profiles of MAA concentration in GKS normalized to the protein or chl a content gave the same distribution pattern (Sommaruga unpubl.).

\section{MAA variability among lakes}

Lakes at high altitude are exposed to high incident UVR (Blumthaler et al. 1993) and are generally highly UV-transparent, as they possess low concentrations of colored dissolved organic matter (Sommaruga et al. 1999, Laurion et al. 2000). Consequently, phytoplankton from those lakes must have different strategies to minimize the potential damage caused by UV. Our series of lakes presented a large variety of UVabsorbing compounds and underwater light conditions. Many of the lakes sampled offered reduced UV refuges with $Z_{1 \%}: Z_{\max }$ (at $320 \mathrm{~nm}$ ) averaging 0.75 (range of 0.004 to 3.8). The relationship between MAAs and UV water transparency clearly shows that phytoplankton from the most transparent lakes possessed the highest concentration of MAAs (Fig. 4A). The variability explained was slightly higher when the MAA concentration was related to absolute values of downwelling UVR at the respective sampling depths. This variable takes into account the differ- 
ences in incident UVR in addition to differences in water column transparencies (although an average of UV irradiance over 1 to $2 \mathrm{~d}$ before sampling would have been more appropriate to reflect the previous history of light exposure). Nevertheless, the variability in MAA concentrations explained by UV water transparency or downwelling UVR was low $(<26 \%)$. These results are in contrast to those found for zooplankton from freshwater lakes where the UV transparency $\left(K_{\mathrm{d}}\right)$ and the $Z_{1 \%}: Z_{\max }$ ratio explained 74 and $86 \%$ of the variability in MAA concentrations among lakes, respectively (Tartarotti et al. 2001). Although normalization of MAA concentration by the chl a content might have introduced a bias caused by the presence of algal groups having different MAA/chl a ratios (or of MAA-containing microzooplankton), our results suggest that the synthesis of MAAs by phytoplankton is affected by factors other than UV transparency. For example, Estany Gran (GRA) and Estany Negre (NEG) had high transparency but low MAA concentrations. These lakes are deep (maximum depth 25 and $70 \mathrm{~m}$, respectively) and had a deep mixed layer at the time of sampling (12 $\mathrm{m}$ for both lakes), suggesting that phytoplankton were exposed to lower daily UV doses than shallower or more stratified lakes with similar UV transparency. Other transparent lakes presenting low MAA concentrations were sampled in October (GKS, MPL, OPL covered by 2 to $3 \mathrm{~cm}$ of ice, and Seebensee [SEE]). At this time of the year, the synthesis of MAAs might not be an advantageous strategy, as incident UVR is relatively low compared to summer values (shorter day length, lower solar angle). Moreover, the variability in MAA concentration among phytoplankton assemblages may be affected by nutrient availability in those lakes. For example, nitrogen is essential for the synthesis of MAAs (Litchman et al. 2002), but the consequences of limitation by phosphorus, which is more typical for freshwaters, has not yet been assessed. In addition, studies have demonstrated that the ability to produce significant amounts of MAAs through photoinduction in phytoplankton is limited to certain species or taxa (Helbling et al. 1996, Hannach \& Sigleo 1998). The model of Garcia-Pichel (1994) suggests that among nanoplankters (cell radii of 1 to $10 \mu \mathrm{m}$, a size-class abundant in many lakes sampled in this study), MAAs can afford benefits only at the expense of relatively important investments and with restricted efficiencies. Finally, repair mechanisms for UV damage is an additional important strategy used by phytoplankton, and the efficiency of repair may influence the algal composition in UV-stressed environments. This strategy might have been especially important in those UV-transparent lakes where sunscreens were less abundant.

\section{Photoprotective carotenoids}

PPCs were detected in several lakes. Three xanthophylls were identified: DIA was found in KLA and MPL, ZEA was present in several lakes, and MYX was detected in almost all lakes (Table 1). DIA is associated with diatoms, chrysophytes, or dinoflagellates, while ZEA and MYX are signature pigments of cyanobacteria. The accumulation of carotenoids under conditions of excessive light is known to play a photoprotective role and is typically observed in surface populations of cyanobacteria, chlorophytes, and redtide dinoflagellates (Pearl et al. 1983, Ben-Amotz et al. 1989, Vernet et al. 1989). Specifically, the xanthophyll cycle plays a photoprotective role by promoting heat dissipation of excess light energy in the light-harvesting centers of chloroplast membranes (Demers et al. 1991). Moreover, Götz et al. (1999) showed that increasing amounts of ZEA resulted in higher protection of photosynthesis against UVB damage in the cyanobacterium Synechococcus PCC7942.

The presence of DIA in MPL and KLA (with $Z_{1 \%}: Z_{\max }$ close to 1) likely indicates another photoprotective strategy used by the algal community of these lakes. Likewise, the highest chl a-specific concentration of ZEA was found in MPL and SOS, 2 lakes with high exposure to UVR (attenuation depth $Z_{1} \%$ at $320 \mathrm{~nm}$ of 7 and $14 \mathrm{~m}$, respectively). Similarly, the concentration of MYX was particularly high in clear lakes such as MPL, ROT, RED, and GKS. Nevertheless, many carotenoids remained unidentified in our study; thus, the importance of carotenoids as an additional photoprotective mechanism needs to be further assessed in these communities.

\section{Diversity of photoprotective compounds}

Although all 7 MAAs were detected in some cases (e.g., in BAR, NEG, and PIB), the most abundant MAAs found in our lake series were SH and PI. This is similar to results on MAA distribution among several marine taxa reviewed by Karentz (2001), where the most frequently found compound was PI, followed by SH. A large diversity of PPCs and the highest concentration of MAAs were found in MPL in July (Table 1; Fig. 6). This lake, located at $2317 \mathrm{~m}$ a.s.l., is one of the most UV-exposed lakes in this series $\left(Z_{1 \%}: Z_{\max }\right.$ of 1.25$)$. This lake had a distinct phytoplankton community, with a dominance of chrysophytes (Ochromonas sp.), dinoflagellates (Gymnodinium sp. and Peridinium sp.), and other small flagellates, and relatively high biomass $\left(2.4 \mu \mathrm{g} \mathrm{chl} \mathrm{a}^{-1}\right)$. Dinoflagellates have been observed to synthesize MAAs and hence tolerate high levels of UVR (Carreto et al. 1990, Negri et al. 1992, Neale et al. 
1998, Jeffrey et al. 1999). This lake also showed a relatively high concentration of MG (1.2 $\left.\mu \mathrm{g} \mathrm{l}^{-1}\right)$, known for its antioxidant function (Dunlap \& Yamamoto 1995) and also large amounts of 3 PPCs, DIA, ZEA, and MYX. The high concentration of MAAs in this lake might have, in turn, influenced the UV transparency, which was relatively high for such a high altitude lake $\left(K_{\mathrm{d} 320}=0.65 \mathrm{~m}^{-1}\right.$; see Laurion et al. 2000). Lake RED was also one of the clearest lakes sampled, but much deeper than MPL (maximum depth of $73 \mathrm{~m}$ ). The thermocline was well established at $14 \mathrm{~m}$ in September, and the complete epilimnion was exposed to more than $1 \%$ of surface UVR (at $320 \mathrm{~nm}$ ). This lake also had high concentrations of MYX and MAAs (and a large diversity, including also MG) but only in the epilimnion (5.2 compared to $0.1 \mu \mathrm{g}$ MAAs [ $\mu \mathrm{g} \mathrm{chl} \mathrm{a}]^{-1}$ at 2 and $25 \mathrm{~m}$, respectively), suggesting again the photoprotective role of these compounds. Other lakes also possessed high MAA diversity (e.g., BAR, GRA, LIC, OBR, and PIB), providing a wide range of wavelengths screened across the UVB and UVA bands.

The absorption peaks around $380 \mathrm{~nm}$ detected in several acetone extracts (see Fig. 2) suggest the presence of scytonemin. This pigment, however, is known to be present only in the sheath of cyanobacterial mats or colonies (Garcia-Pichel \& Castenholz 1991). While filamentous or colonies of cyanobacteria were only observed in some lakes and in low abundance (OBR, PIB, PJO, PRA, TOR), the volume used for microscopic observation was much smaller than that filtered for pigment analyses $(60 \mathrm{ml}$ sedimented compared to several liters filtered). On the other hand, peaks at 370 to $378 \mathrm{~nm}$ have also been reported for cultures of the dinoflagellate Gymnodinium catenatum (Jeffrey et al. 1999). These authors suggested that this unknown compound could be a new class of UV-absorbing compounds or the cis-peak form of a carotenoid. Nevertheless, the presence of this UVA-absorbing compound found in lakes with the highest UV exposure suggests a photoprotective role.

\section{CONCLUSIONS}

Our results show the widespread occurrence of photoprotective compounds (MAAs and carotenoids) among freshwater phytoplankton assemblages in lakes of very different characteristics. While the highest concentrations of these compounds were found in the clearest lakes, the relationship between UV exposure and concentration among these lakes was not straightforward. For instance, the phytoplankton of some UV-transparent lakes did not synthesize significant amounts of MAAs. Variables other than UV exposure that may affect phytoplankton community composition such as temperature, $\mathrm{N}: \mathrm{P}$ ratios, and $\mathrm{pH}$ probably added variability to the data set analyzed. Consequently, to identify the environmental factors regulating the synthesis of photoprotective compounds in freshwater phytoplankton assemblages, it will be necessary to do experiments considering, for example, nutrient enrichment and exposure to specific wavelengths of the solar spectrum.

Acknowledgements. We thank M. Ventura, J. Chiapella, D. Conde, P. Indinger, A. Miro, and A. Wille for their assistance in field and laboratory work, R. Lackner for HPLC assistance, D. Karentz, M. Shick, and F. Garcia-Pichel for donating standards or biological material to identify the MAAs, and 3 anonymous reviewers for helpful comments on the manuscript. We also thank the staff from Aiguestortes i estany de Sant Maurici National Park for facilitating the sampling of most lakes in the Pyrenees. The research was supported by a grant from the Austrian Science Foundation (FWF P14153$\mathrm{BIO})$ to R.S. and the Austrian Ministry of Agriculture and Forestry (BMLF 41.001/14-IVA1/98) to R. Psenner and R.S. FCAR funds (Fonds pour la Formation de Chercheurs et l'Aide à la Recherche) provided a post-doctoral fellowship to I.L. Travel to Spain was financed by the collaborative scientific program between Austria and Spain (Contract No. 98/17).

\section{LITERATURE CITED}

Ben-Amotz A, Shaish A, Avron M (1989) Mode of action of the massively accumulated $\beta$-carotene of Dunaliella bardawil in protecting the alga against damage by excessive radiation. Plant Physiol 91:1040-1043

Bidigare RR, Ondrusek ME, Kennicutt MC, Iturriaga RH, and 3 others (1993) Evidence for a photoprotective function for secondary carotenoids of snow algae. J Phycol 29:427-434

Bidigare RR, Iriarte JL, Kang SH, Ondrusek ME, Karentz D, Fryxell GA (1996) Phytoplankton: quantitative and qualitative assessments. Foundations for ecosystem research in the western Antarctic peninsula region. Antarctic Res Ser 70:173-198

Blumthaler M, Ambach W, Huber M (1993) Altitude effect of solar UV radiation dependent on albedo, turbidity and solar elevation. Meteorol Z 2:116-120

Bracher AU, Wiencke C (2000) Simulation of the effects of naturally enhanced UV radiation on photosynthesis of Antarctic phytoplankton. Mar Ecol Prog Ser 196:127-141

Buckley CE, Houghton JA (1976) A study of the effects of near UV radiation on the pigmentation of the blue-green alga Gloeocapsa alpicola. Arch Microbiol 107:93-97

Carefoot TH, Harris M, Taylor BE, Donovan D, Karentz D (1998) Mycosporine-like amino acids: possible UV protection in eggs of the sea hare Aplysia dactylomela. Mar Biol 130:389-396

Carreto JI, Carignan MO, Daleo G, De Marco SG (1990) Occurrence of mycosporine-like amino acids in the redtide dinoflagellate Alexandrium excavatum: UV-photoprotective compounds? J Plankton Res 12:909-921

Davidson AT, Bramich D, Marchant HJ, McMinn A (1994) Effects of UV-B irradiation on growth and survival of Antarctic marine diatoms. Mar Biol 119:507-515

Demers S, Roy S, Gagnon R, Vigneault C (1991) Rapid lightinduced changes in cell fluorescence and in xanthophyll- 
cycle pigments of Alexandrium excavatum (Dinophyceae) and Thalassiosira pseudonana (Bacillariophyceae): a photoprotection mechanism. Mar Ecol Prog Ser 76:185-193

Dunlap WC, Yamamoto Y (1995) Small molecule antioxidants in marine organisms: antioxidant activity of mycosporineglycine. Comp Biochem Physiol 112B:105-114

Dunlap WC, Williams DM, Chalker BE, Banaszak AT (1989) Biochemical photoadaptations in vision: UV-absorbing pigments in fish eye tissues. Comp Biochem Physiol 93B:601-607

Garcia-Pichel F (1994) A model of internal self-shading in planktonic organisms and its implication for the usefulness of ultraviolet sunscreens. Limnol Oceanogr 39: 1704-1717

Garcia-Pichel F, Castenholz RW (1991) Characterization and biological implications of scytonemin, a cyanobacterial sheath pigment. J Phycol 27:395-409

Goes JI, Handa N, Tagushi S, Hama T (1994) Effect of UV-B radiation on the fatty acid composition of the marine phytoplankter Tetraselmis sp.: relationship to cellular pigments. Mar Ecol Prog Ser 114:259-274

Götz T, Windhövel U, Böger P, Sandmann G (1999) Protection of photosynthesis against UV-B radiation by carotenoids in transformants of the cyanobacterium Synechococcus PCC7942. Plant Physiol 120:599-604

Hannach G, Sigleo AC (1998) Photoinduction of UV-absorbing compounds in six species of marine phytoplankton. Mar Ecol Prog Ser 174:207-222

Helbling EW, Chalker BE, Dunlap WC, Holm-Hansen O, Villafañe VE (1996) Photoacclimation of Antarctic marine diatoms to solar ultraviolet radiation. J Exp Mar Biol Ecol 204:85-101

Jeffrey SW, Humphrey GF (1975) New spectrophotometric equations for determining chlorophylls $\mathrm{a}, \mathrm{b}$ and $\mathrm{c}$ and $\mathrm{c} 1$ in higher plants, algae and natural phytoplankton. Biochem Physiol Pflanz 167:191-194

Jeffrey SW, McTavish HS, Dunlap WC, Vesk M, Groenewoud K (1999) Occurrence of UVA- and UVB-absorbing compounds in 152 species (206 strains) of marine microalgae. Mar Ecol Prog Ser 189:35-51

Karentz D (2001) The chemical defenses of marine organisms against solar radiation exposure: UV-absorbing mycosporine-like amino acids and scytonemin. In: McClintock JB, Baker BJ (eds) Marine chemical ecology. CRC Press, Boca Raton, p 481-511

Karentz D, McEuen FS, Land MC, Dunlap WC (1991) Survey of mycosporine-like amino acid compounds in Antarctic marine organisms: potential protection from ultraviolet exposure. Mar Biol 108:157-166

Kinzie RA III, Banaszak AT, Lesser MP (1998) Effects of ultraviolet radiation on primary productivity in a high altitude tropical lake. Hydrobiologia 385:23-32

Laurion I, Ventura M, Catalan J, Psenner R, Sommaruga R (2000) Attenuation of ultraviolet radiation in mountain lakes: factors controlling the among- and within-lake variability. Limnol Oceanogr 45:1274-1288

Litchman E, Neale PJ, Banaszak AT (2002) Increased sensitivity to ultraviolet radiation in nitrogen-limited dinoflagellates: photoprotection and repair. Limnol Oceanogr 47:86-94

Mantoura RFC, Llewellyn CA (1983) The rapid determination of algal chlorophyll and carotenoid pigments and their breakdown products in natural waters by reverse-phase high-performance liquid chromatography. Anal Chim

Editorial responsibility: William Li,

Dartmouth, Nova Scotia, Canada
Acta 15:297-314

Marchant HJ, Davidson AT, Kelly GJ (1991) UV-B protecting compounds in the marine algae Phaeocystis pouchetii from Antarctica. Mar Biol 109:391-395

Neale PJ, Banaszak AT, Jarriel CR (1998) Ultraviolet sunscreens in Gymnodinium sanguineum (Dinophyceae): mycosporine-like amino acids protect against inhibition of photosynthesis. J Phycol 34:928-938

Negri RM, Carreto JI, Benavides HR, Akselman R, Lutz VA (1992) An unusual bloom of Gyrodinium cf. aureolum in the Argentine sea: community structure and conditioning factors. J Plankton Res 14:261-269

Pearl HW, Tucker J, Bland PT (1983) Carotenoid enhancement and its role in maintaining blue-green algal (Microcystis aeruginosa) surface blooms. Limnol Oceanogr 28: 847-857

Riegger L, Robinson D (1997) Photoinduction of UV-absorbing compounds in Antarctic diatoms and Phaeocystis antarctica. Mar Ecol Prog Ser 160:13-25

Roy S (2000) Strategies for the minimisation of UV-induced damage. In: de Mora S, Demers S, Vernet M (eds) The effects of UV radiation in the marine environment. Cambridge University Press, Cambridge, p 177-205

Shick JM, Romaine-Lioud S, Ferrier-Pagès C, Gattuso JP (1999) Ultraviolet-B radiation stimulates shikimate pathway-dependent accumulation of mycosporine-like amino acids in the coral Stylophora pistillata despite decreases in its population of symbiotic dinoflagellates. Limnol Oceanogr 44:1667-1682

Sommaruga R, Garcia-Pichel F (1999) UV-absorbing mycosporine-like compounds in planktonic and benthic organisms from a high-mountain lake. Arch Hydrobiol 144: 255-269

Sommaruga R, Psenner R, Schafferer E, Koinig KA, Sommaruga-Wögrath S (1999) Dissolved organic carbon concentration and phytoplankton biomass in high-mountain lakes of the Austrian Alps: potential effects of climatic warming on UV underwater attenuation. Arct Antarct Alp Res 31:247-254

Tartarotti B, Laurion I, Sommaruga R (2001) Large variability in the concentration of mycosprine-like amino acids among zooplankton from lakes located across an altitude gradient. Limnol Oceanogr 46:1546-1552

Tsujino I, Yabe K, Sakurai M (1979) Presence of the near $358 \mathrm{~nm}$ UV-absorbing substances in red algae. Bull Fac Fish Hokkaido Univ 30:100-108

Vernet M, Neori A, Haxo FT (1989) Spectral properties and photosynthetic action in red-tide populations of Prorocentrum micans and Gonyaulax polyedra. Mar Biol 103: $365-371$

Villafañe VE, Helbling EW, Holm-Hansen O, Chalker BE (1995) Acclimatization of Antarctic natural phytoplankton assemblages when exposed to solar ultraviolet radiation. J Plankton Res 17:2295-2306

Whitehead K, Vernet M (2000) Influence of mycosporine-like amino acids (MAAs) on UV absorption by particulate and dissolved organic matter in La Jolla Bay. Limnol Oceanogr 45:1788-1796

Xiong FS, Kopecky J, Nedbal L (1999) The occurrence of UV$\mathrm{B}$ absorbing mycosporine-like amino acids in freshwater and terrestrial microalgae (Chlorophyta). Aquat Bot 63: $37-49$

Zar JH (1999) Biostatistical analysis. Prentice-Hall Inc, Englewood Cliffs

Submitted: July 31, 2001; Accepted: November 22, 2001

Proofs received from author(s): January 7, 2002 